\title{
INSTEAD OF INTRODUCTION: HOW OLD IS SACREDNESS?
}

\author{
Tõnno Jonuks \\ PhD, Research Professor \\ Estonian Literary Museum, Estonia \\ Research Fellow \\ School of Humanities, Tallinn University, Estonia \\ tonno.jonuks@folklore.ee
}

It is customary that references to history are used to legitimise one's ideological and religious statements. This method is particularly visible in contemporary pagan and spiritual movements, in which history has a crucial position not only in justifications of religious claims but also in searching inspiration for contemporary beliefs and for providing a structural framework for (re)constructing past religions. The commonest explanation for using history in arguments and rhetoric in religion is to add credibility to one's claims. Examples can be found in traditional institutional religious organisations, in contemporary spiritual movements, but also in the rhetoric of individual charismatic leaders. Such rhetorical manner is not common to contemporary religions only but can also be followed in historical folk religion (see, e.g., Johanson 2018). For instance, in a record of a heavily worn eighteenth-century copper coin, used for healing magic in the early twentieth century, the old age of the coin is specifically valued (Fig. 1).

According to a legend, copper was filed from a coin to help people and animals to recover from bone fractures. The same can also be observed in magical customs, including, for instance, preference for older prints of the Bible for magical rituals (see, e.g., Kõiva 2017: 144). These examples demonstrate how references to history add somewhat stronger and more serious attributes to an object or a claim.

The role of history is also apparent in the rhetoric - either in that of a religious group or in the wording of academic studies. It is probably often unconscious, but the mapping of the usage of adverbs of time, such as 'yet' or 'still', provides a good example. These words create a suitable context for leaving an 


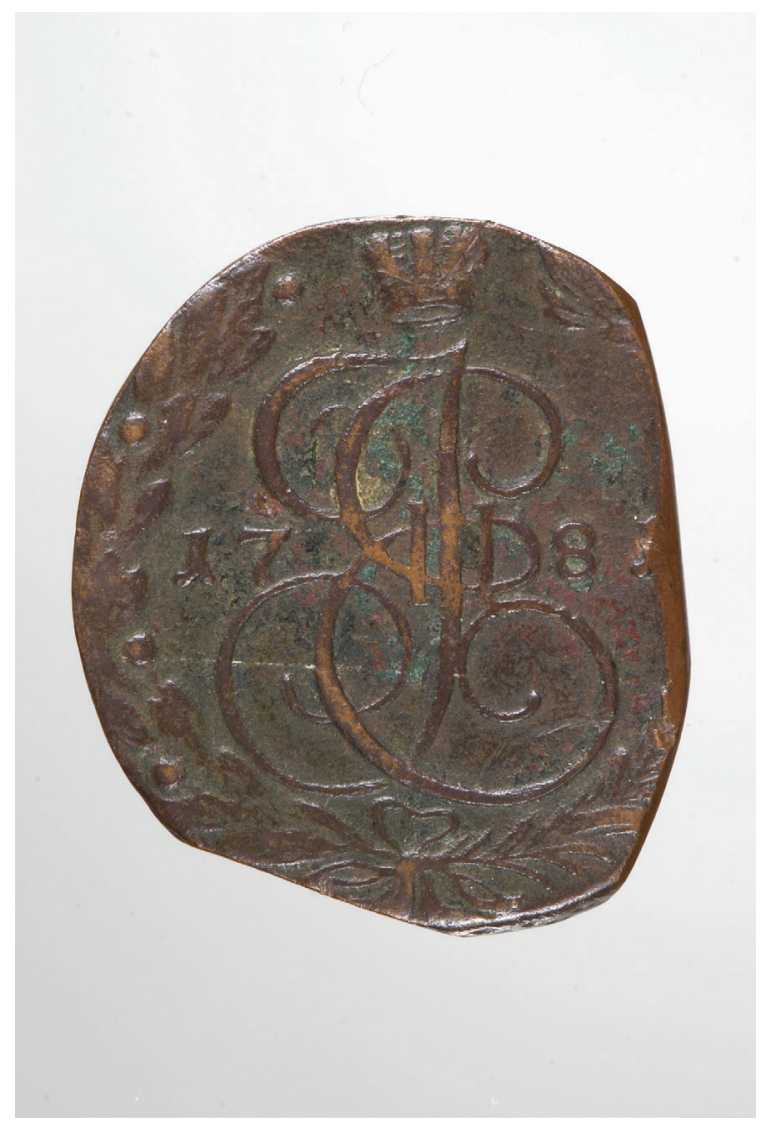

Figure 1. When a bone was broken, either of a man or an animal, copper was filed from such a coin into water, and it was given to drink to the patient. Copper was supposed to heal the fracture. Old people say that copper powder was often found at the animals' bone fractures that had been treated like that. This means, they believed that copper moved to the [broken] bone. A broken leg was secured tightly with four splints and then 'copper drinking' followed. Older copper coins were used. Modern coins were not supposed to be of pure copper. Larger coins were usually used. (ERM 14356) Photograph by courtesy of the Estonian National Museum.

impression of the old age of some phenomena and due to such a context a more detailed study about the age of some particular details seems unnecessary. A good example comes from the modern discourse of Estonian natural sacred places, often related to pre-Christian traditions. One of the arguments in support of this view is a repeated claim in internet sources, popular writings, but often also in academic articles, that offerings are still brought to Estonian sacred sites nowadays. Such phrasing leaves a distinct impression of a continuous tradition of worshipping sacred places and leaving deposits since ancient paganism. Although the sources for studying the usage of sacred sites in Estonia are scarce, it is apparent that the modern tradition to leave deposits was initiated at the end of the 1980s and became widely acknowledged only in the 2000s (in more detail see Jonuks \& Äikäs 2019).

Nevertheless, the continuity of sacred sites is a crucial concept and even if no evidence exists, the desire to prove the old age of natural sacred places 
is apparent. The Estonian sacred sites in nature, some of which undoubtedly have a long history, attracted attention anew in the late $1980 \mathrm{~s}$, together with the national and independence movement. Since then, the main organisation to guide ordinary people to understand the sites has been a contemporary pagan movement called maausk (earth-belief) and its official organisation Maavalla Koda. The maausk organisation has had a very successful branding (as Ringo Ringvee (2017: 64) has stated) in comparison to other contemporary pagan movements in Northern Europe. The organisation was founded in the 1990s as a religious union but since the 2000 s the spokespersons have changed the public focus from the pagan religion to general cultural, national, and heritage issues. In numerous articles (over 700 in four years!) published in local newspapers and popular journals they have not advertised Maavalla Koda as a religious community but rather as a union to join and represent people who are interested in and concerned about Estonian cultural heritage, and to preserve sacred sites as cultural objects. Sacred sites are presented in this view as places inherited from Estonian history and defining Estonian national identity. These are also demonstrated as sites from pre-Christian paganism, which are not preserved in such a good condition elsewhere in Europe. Linking the sacred places with national identity and Estonian culture has brought the whole subject to the next level, resulting in general appreciation of the sites, where pagan understandings are also shared by people who themselves do not belong to pagan communities or identify themselves as pagans. This has created a fruitful context for the general acknowledging of pagan ideas, so that Estonia in general is described as following the "nature-loving precepts of neo-paganism" (The Economist 2017).

Estonian natural sacred sites are usually determined by the followers of the contemporary pagan community as being old, ancient, or originating from times immemorial. As the main source for natural sacred places is folklore, which in most cases is undatable, such uncertain dates are the best that can be achieved. Likewise, the chronicles and written sources from the Middle Ages and early modern period provide only scarce data. From the Middle Ages there are only a few records that can be associated with a site. Early modern writings provide some good descriptions of locals acting superstitiously, and usually confirm that sacred places are old cultic sites. In fact, when following the descriptions in detail, it appears that what has been described as 'pagan' customs are often just Catholic traditions or folk interpretations of Catholic rituals that were regarded as superstitious deeds by the local Lutheran clerics after the Reformation and reinterpreted as pre-Christian paganism by scholars in the nineteenth and twentieth centuries. Archaeology as the main discipline concentrating on dates and identifying the age of sites has been useless as, due to the general 
lack of finds, occupation layers or constructions, the traditional archaeological methods to precisely date the use of sacred sites cannot be applied.

In most cases such vague dates are sufficient for spiritual purposes and there is no need to further discuss how old sacredness is. However, in certain cases, when academic knowledge and spiritual practices meet or when a site becomes a centre of some conflict, the exact dating of a site becomes essential. In a recent case from 2017, the cutting down of a willow tree in Tallinn caused a conflict and a heated argument between infrastructure developers and environmental protectors. The age of this tree, estimated from a couple of decades to 300 years, became an important argument for both sides, demonstrating clearly how history matters in such conflicts.

In speculations about the age of sacred sites I have found three different approaches in Estonian media - poetic, pagan, and folksy (popular). The fourth approach - academic - is unfortunately largely missing. All these approaches use different methods, they reach different results, and sometimes they also compete with each other.

In most cases the age of a place has been identified only as 'old' in popular culture, characteristic of what can be labelled as poetic dating. While considered insufficient in academic studies, such a dating is fine in spiritual communities and even more - such a vague statement adds an amount of mysticism. Sacred places are mysterious sites and people know very little about them; their origin is hidden; sites are so sacred that people are not allowed to know about them anymore. In such emotional expressions the unidentified age becomes a positive feature, and the lack of clear academic data adds a certain value. In this tradition the age of sacred places has usually been determined to be a millennium. For a historian this means 1,000 years, that is ten to eleven centuries, but what is really meant is just old. Besides, following the general narrative of Estonia, the sacred sites supposedly originate from the pre-Christian independence period and here the estimation 'millennium' fits neatly.

The pagan approach to date sacred sites is somewhat similar, as the mystic component clearly exists. According to the pagan teaching, the sacredness of a site originates from nature and not from the human - a statement that makes the dating of sacred places irrelevant. Accordingly, it could only be dated when people discovered the sacredness of a particular place, but even this is not essential. Thus, the pagan community is in most cases satisfied that sacred places are just old and undatable. In this view, it is often also combined with the poetic approach. A good example of pagan dating is Vällamägi Hill in south-eastern Estonia.

According to the pagan approach, this is the oldest sacred place in Estonia as the retreating margin of the ice sheet moved from the south-east to the north- 


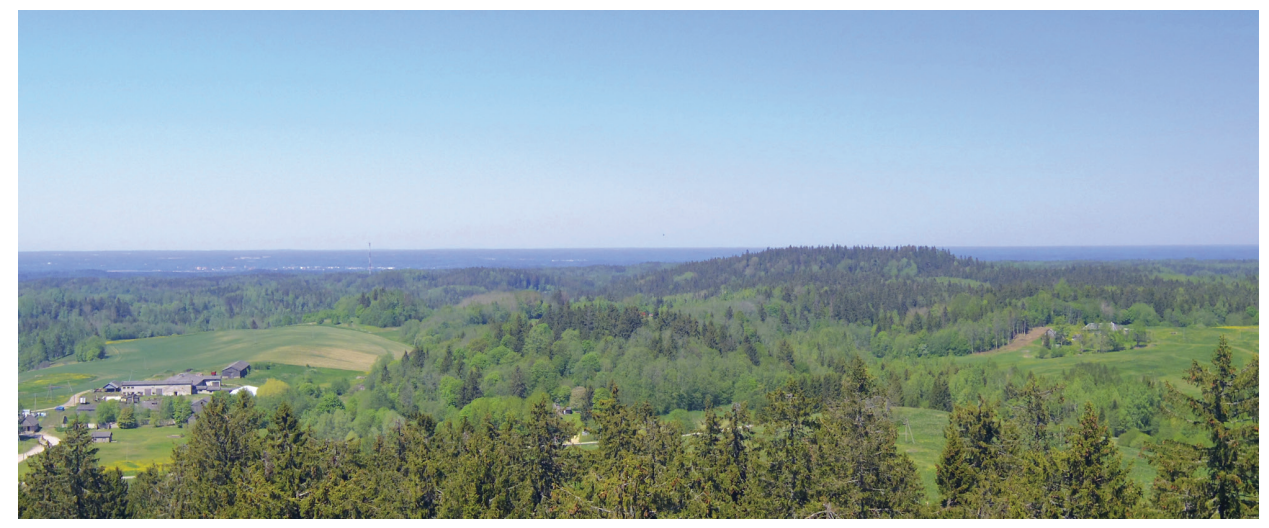

Figure 2. Vällamägi Hill - the oldest sacred place in modern Estonia? Photograph by Andres Kuperjanov 2018.

west at the end of the last glacial period, leaving behind moraines. This means that the ground of today's Estonia was first uncovered in the south-eastern corner of the country, exposing also the area of the present-day Vällamägi moraine hill, which became the earliest sacred place in Estonia (Kaasik 2016: 21). In this view the possible human utilisation of the sacred place is really not relevant.

On the other hand, as demonstrated above, the spokespersons of the pagan community also wish to contribute to heritage studies, which has directed them more to the academic style. Also the general public, especially the readership of local newspapers, associates pagan authors in Estonia with popular or academic historians, and this also seems to be the intention of the authors themselves. In various articles the usage of academic phrasing leaves an impression as if the author understands the limits of academic approaches and the basic source criticism. Moreover, the source-critical approach also adds a significant portion of academic style and credibility. Some single examples of the contemporary pagan community supporting a precise date are very clearly based on historical data. For instance, a sacred tree at Palivere, western Estonia, is dated to the sixteenth century as the site is mentioned in a local church chronicle and, additionally, a sixteenth-century coin has been found on the site (Relve 2003: 116).

Such precise dates are, however, more important for a broader audience, and are related to the folksy approach. An ordinary reader, who often shares the worldview and values rooted in the pagan community, still yearns for a historical approach which is common in popular science. Academic phrasing and accurate dates seem more serious in this approach, add a significant amount of credibility and scientific character, and leave an impression as if the author knows what 
they are writing/talking about. Differently from the previous ones, the main criterion in the folksy approach is to date human activity at sacred sites rather than the sacrality inherited from the nature. And unlike the poetic approach, which is satisfied with and rather values vagueness, the folksy method seeks for seemingly academic methodology, also suggesting archaeological excavations at sacred places. In the folksy tradition sacred places belong to a pre-Christian period and are characteristic of Estonians by default. It is interesting, however, that although the precise dating is available, the method used is not important and this has resulted in rather brave attempts to date sacred sites.

In the vicinity of Tallinn there is a sacred grove called Pärnamäe, the age of which has been determined to be 6,500 years (Taarausulised 2001). However, despite my attempts, it has been impossible to find out how such a result was achieved. In popular publications and speeches this date has been offered as granted, without explaining from where it originates. For a broader audience this is clearly sufficient enough and further discussions about the methodology are not needed. Following the Estonian national narrative, the arrival of the Estonian nation to the territory of today's Estonia has traditionally been related to comb-ceramic culture, which appeared just about the same period - $3900 \mathrm{BC}$ according to the most recent datings. Possibly the age of the Pärnamäe sacred grove is elicited from this context and it is assumed that the Stone Age Estonians started to use sacred sites (as is also reflected in Estonian oral tradition), and this indicates the age of the Pärnamäe sacred grove.

The examples above demonstrate expressively how history matters in spiritual and pagan contexts. Although history is usually not placed in the primary position, it forms a necessary background, provides contexts for various claims, and is a source of inspiration. It also means that history matters only selectively, in the cases where carefully chosen facts and pieces are combined for the sake of contemporary needs. The core of this issue of Folklore: Electronic Journal of Folklore originates from the end of 2017, from a session titled "History matters" at an annual conference of the Centre of Excellence in Estonian Studies (TK-145). ${ }^{1}$ The session analysed strategies for using history in contemporary religious ideologies and rhetoric, asking the following questions: What is the role of academic history, archaeology, and folklore in contemporary spiritual movements? What sort of arguments are used and what arguments are ignored in spiritual ideologies? How are historical facts changed or modified for the sake of contemporary needs? How is the concept of continuity understood in these movements? It is also interesting to realise that the process of using history for religious argumentations is not one-way - the popular and widely acknowledged pagan communities can also influence academic research, either consciously or unconsciously (see, e.g., Jonuks 2018). 
The session brought together fourteen scholars from various countries to discuss the usage of history in religions. Geographically discussions focused on Central and Eastern Europe and Russia and formed a well-communicating group of presentations. The discussed topics varied, ranging from the general frameworks of modern religious and spiritual movements to specific discussions of some phenomena. Several years later part of the presentations from the session "History matters" have found their way to this journal. Unfortunately, not all the presentations in the session resulted in an article in this issue for various reasons - some of the articles had already been published elsewhere, others remained as preliminary presentations. In addition to Ceri Houlbrook, Kurmo Konsa, Atko Remmel and Tõnno Jonuks, and Siarhei Anoshka from the session, this issue also includes Eda Kalmre's article about apparent death and Alise Donnere's study on interpreting Bodhisattva Jizō in Japanese temples, both following the same approach as the conference session. All the authors have kept the role of the concept of history in different religious or spiritual contexts under careful observation, demonstrating, either consciously or unconsciously, its central position in the formation of claims and arguments.

\section{ACKNOWLEDGEMENTS}

This article was supported by the research grant of the Estonian Literary Museum EKM 8-2/20/3 and by the Centre of Excellence in Estonian Studies (TK 145) through the European Regional Development Fund.

\section{NOTES}

1 See https://www.folklore.ee/CEES/2017/akonve_e.htm, last accessed on 17 February 2021.

\section{REFERENCES}

Johanson, Kristiina 2018. Missing Interpretations: Natural and Residual Finds in Estonian Archaeological Collections. Diss. (PhD Thesis). Tartu: Tartu Ülikooli Kirjastus. Available at https://dspace.ut.ee/handle/10062/62834, last accessed on 17 February 2021. 
Jonuks, Tõnno 2018. New Trends in the Study of Religion in Estonia: Contemplations in the Grey Zone between Religion and Science. In: Ekaterina Anastasova \& Mare Kõiva (eds.) Balkan and Balticum: Current Studies in the Postsocialist Space. Sator 18. Tartu: ELM Scholarly Press, pp. 161-182. https://doi.org/10.7592/ Sator.2017.18.08.

Jonuks, Tõnno \& Äikäs, Tiina 2019. Contemporary Deposits at Sacred Places: Reflections on Contemporary Paganism in Estonia and Finland. Folklore: Electronic Journal of Folklore, Vol. 75, pp. 7-46. https://doi.org/10.7592/FEJF2019.75.jonuks_aikas.

Kõiva, Mare 2017. Loitsud ja rahvaarstid Virumaal. [Healers and Charms in Virumaa.] Mäetagused, Vol. 67, pp. 141-180. http://dx.doi.org/10.7592/MT2017.67.koiva.

Kaasik, Ahto 2016. Põlised pühapaigad: Oleme hiierahvas. [Ancient Holy Places: We Are a Hiis People.] Tallinn: Pegasus.

Relve, Hendrik 2003. Põlispuud. [Primeval Trees.] Tallinn: Koolibri.

Ringvee, Ringo 2017. Survival Strategies of New Religions in a Secular Consumer Society: A Case Study from Estonia. Nova Religio: The Journal of Alternative and Emergent Religions, Vol. 20, No. 3, 57-73. https://doi.org/10.1525/nr.2017.20.3.57.

Taarausulised 2001 = Taarausulised korrastavad Eesti vanimat hiit. [Taara Faith Followers Tend the Oldest Hiis Site in Estonia.] Postimees, 27 September. Available at https://www.postimees.ee/1893851/taarausulised-korrastavad-eestivanimat-hiit, last accessed on 17 February 2021.

The Economist 2017 = Estonia Is Trying to Convert the EU to Its Digital Creed. The Economist, 8 July. Available at https:/www.economist.com/europe/2017/07/06/ estonia-is-trying-to-convert-the-eu-to-its-digital-creed, last accessed on 18 February 2021.

Tõnno Jonuks is Research Professor (PhD) at the Estonian Literary Museum and Research Fellow at Tallinn University. His main research concerns Estonian religion in the past, material sources of religion, and animal symbolism in Estonia.

tonno.jonuks@folklore.ee 